\title{
Parenteral Beslenen Yoğun Bakım Hastalarında Soya Yağı, Zeytinyağı ve Mct-Lct Bazlı Nutrisyon Solüsyonlarının Etkilerinin Karşılaştırılması
}

\author{
Comparison of Effects of Soy Oil, Olive Oil, Mct-Lct Based Nutrition \\ Solutions in Parenterally Fed Intensive Care Patients
}

\author{
Nurşen Gürsoy, Çetin Kaymak*, Ayşe Özcan*, Namık Özcan*, Turgut Çavuşoğlu**, Mustafa Kotanoğlu*, Hülya Başar* \\ Sağlık Bakanlığı Bozüyük Devlet Hastanesi, Anesteziyoloji ve Reanimasyon Kliniği, Bilecik, Türkiye \\ *Sağlık Bakanlığı Ankara Eğitim Araştırma Hastanesi, Anesteziyoloji ve Reanimasyon Kliniği, Ankara, Türkiye \\ **Sağlık Bakanlığı Ankara Eğitim Araștırma Hastanesi, Genal Cerrahi Kliniği, Ankara, Türkiye
}

\section{ÖZET}

Amaç: Bu çalışmada, parenteral yoldan farklı lipid içeren nutrisyon solüsyonu ile beslenen yoğun bakım hastalarında biyokimyasal parametrelerdeki değişikliklerin ve nutrisyonun etkinliğinin karşılaştırılması amaçlanmıştır.

Gereç ve Yöntem: Çalışmaya dahil edilen 45 yoğun bakım hastası, soya yağı bazlı (Grup 1), zeytinyağı bazlı (Grup 2) ve MCT/LCT bazlı (Grup 3) lipid içeren nutrisyon solüsyonu almak üzere randomize olarak 3 gruba ayrıldı. Hastaların gereksinimleri olan kalori Schofield eşitliği kullanılarak hesaplandı. Parenteral nutrisyon tedavisi süresince 1, 7 ve 14. günlerde serum albümin, total protein, ALT, AST, LDH, GGT, ALP, glukoz, trigliserid, kolesterol, LDL, HDL, APTT, PT, INR, CRP, transferin ve prealbümin düzeyleri çalışıldı.

Bulgular: Gruplar arası karşılaștırmalarda 1. gün, 7. gün, 14. gün serum glukoz ortalamaları, karaciğer fonksiyon testleri, trigliserid, kolesterol, LDL, HDL, PT, INR ve aPTT değerleri arasında istatistiksel olarak anlamlı fark gözlenmedi. CRP ve prealbümin düzeyleri arasında gruplar arası ve grup içi karşılaştırmalarda istatistiksel olarak anlamlı farklılık bulunmadı. CRP ve prealbümin beraber değerlendirildiğinde, Grup II ve III'te prealbümin düzeyinde artış saptanırken; eş zamanlı olarak serum CRP düzeylerinde azalma saptandı.

Sonuç: Soya yağı, zeytinyağı ve MCT/LCT bazlı parenteral nütrisyon solüsyonu ile beslenen yoğun bakım hastalarında biyokimyasal parametreler ve nutrisyon etkinliği açısından fark bulunmamıştır. (Türk Yoğun Bakım Derneği Dergisi 2012; 10: 52-8)

Anahtar Kelimeler: Yoğun bakım, parenteral nutrisyon, lipid

\section{SUMMARY}

Objective: In this study, we aimed to compare the changes in biochemical parameters and efficacy of nutrition by using parenteral nutrition solutions with different lipid content in critically ill patients.

Material and Method: Fourty-five intensive care patients were randomized into three groups to receive either soy bean based (Group 1) or olive oil based (Group 2) or MCT/LCT based (Group 3) nutrition solutions. The calorie requirement was calculated using Schofield equation day. The levels of albumin, total protein, AST, ALT, LDH, GGT, ALP, glucose, triglyceride, cholesterol, $L D L, H D L, a P T T, P T, I N R, C R P$, transferin and prealbumin were measured on days 1,7 and 14 .

Results: There was no statistically significant difference between groups according to glucose, liver function tests, triglyceride, cholesterol, LDL, HDL, aPTT, PT, INR levels. CRP and prealbumin were similar within-group and between-group comparisons. In groups II and III, CRP levels decreased while prealbumin levels were increasing. Conclusion: As a conclusion, no difference was found comparing the biochemical parameters and efficacy of nutrition, in ICU patients fed with soy oil, olive oil or MCT/LCT based parenteral nutrition solutions. (Journal of the Turkish Society Intensive Care 2012; 10: 52-8)

Key Words: Intensive care, parenteral nutrition, lipid

15. Ulusal Yoğun Bakım Kongresi, Çeşme, İzmir, 5-8 Mayıs 2010'da poster bildirisi olarak sunulmuştur.

Yazışma Adresi/Address for Correspondence: Dr. Namık Özcan, Sağlık Bakanlığı Ankara Eğitim Araştırma Hastanesi, Anesteziyoloji ve Reanimasyon Kliniği, Ankara, Türkiye Tel.: +90 3125953175 E-posta: namikozcan@gmail.com Geliş Tarihi/Received: 26.06.2012 Kabul Tarihi/Accepted: 30.07.2012 


\section{Giriş}

Yoğun bakımda, kritik hastalığa karşı oluşan metabolik yanıt sonucu hastaların yaklaşık \%40'ında protein ve enerji malnutrisyonu gözlenmektedir (1,2). Bu durum artmış nozokomiyal infeksiyon riski, kötü yara iyileşmesi, artmış dekübit ülser riski ve çoklu organ yetmezliği gibi komplikasyonlara yol açarak hem yoğun bakımda kalış süresinin uzamasına, hem de morbidite ve mortalitede artışa neden olmaktadır (1-3). Yoğun bakım hastalarında metabolizma cerrahi hastalarından farklıdır ve ağır malnutrisyonlu yoğun bakım hastaları için nutrisyonel destek, artık standart tedavi olarak kabul edilmektedir. Güncel rehberlerde gastrointestinal traktusun fonksiyonel olduğu durumlarda enteral nutrisyona mümkün olan en kısa sürede başlanılması önerilmektedir (1). Yoğun bakım yatışından sonraki 24 saat içerisinde enteral nutrisyon yapılamayacak olan hastalarda parenteral nutrisyon uygulanması önerisi düzey B derecesinde kanıta sahiptir (4).

Sepsis, travma ve yanıkta en fazla olmak üzere tüm yoğun bakım hastalarında özellikle doku inflamasyonundan ve santral sinir sisteminden kaynaklanan yoğun bir stres yanıtı mevcuttur $(5,6)$. Makronutrientlerin okside olması ile açığa çıkan enerjinin, hücresel düzeyde yüksek enerjili fosfatların yapımı ve depolanması için harcandığı bilinmektedir $(7,8)$. Parenteral nutrisyon ile uygun kalorinin sürekli verilmesinin toplam enerji tüketiminde anlamlı bir artış oluşturmaması, sürekli nutrisyon tekniği ile nutrientlerin daha fazla yakıt olarak kullanılması, daha az depolanması, depolanma için ayrılan enerji miktarını azaltması açısından daha efektif olduğu belirtilmiştir (9).

Soya yağı kaynaklı Omega-6 yağ asitleri özellikle Akut Respiratuar Distres Sendromu (ARDS) olan kritik hastalarda proinflamatuar etkiye ve zararlı potansiyele sahip olabilmektedirler $(10,11)$. Bu nedenle, Omega- 6 yağ asitlerinin anti-inflamatuar etkili, balık yağı kaynaklı Omega-3 yağ asitleri, zeytinyağı kaynaklı Omega-9 yağ asitleri veya orta zincirli yağ asitleri (MCT) ile kombine edilmesi proinflamatuvar etkinin sınırlandırımasında yararlı olabilir (12-17).

Bu çalışmada, farklı etkilere sahip lipid içerikleri olan parenteral nütrisyon solüsyonları ile beslenen yoğun bakım hastalarında, biyokimyasal parametrelerdeki değişikliklerin ve nütrisyonun etkinliğinin karşılaştırılması amaçlanmıştır.

\section{Gereç ve Yöntem}

Çalışmaya, etik kurul izni ve hasta veya hasta yakınından bilgilendirilmiş onam formu alındıktan sonra, yoğun bakım ünitesine yatan ve tek başına parenteral nutrisyon tedavisi başlanan 45 hasta dahil edildi. Böbrek veya karaciğer fonksiyon bozukluğu olan, parenteral nutrisyon tedavisi devam ederken, takiplerinde sepsis, hemodinamik instabilite gelişen, oral ya da enteral nutrisyon desteği de başlanan hastalar çalışma dışı bırakıldı. Hastalar, soya yağı bazlı (Grup 1), zeytinyağı bazlı (Grup 2) ve MCT/LCT (uzun zincirli trigliserid) bazlı (Grup 3) lipid içeren nutrisyon solüsyonu almak üzere randomize olarak 3 gruba ayrıldı. Çalışmaya dahil edilen hastaların yaş, cinsiyet, kilo, boy, beden kitle indeksi gibi demografik verileri kaydedildi.

Hastaların gereksinimleri olan kalori Schofield eşitliği kullanılarak, protein miktarı $1.2 \mathrm{gr} / \mathrm{kg} / \mathrm{gün}$ olacak şekilde hesaplandı (17). Hastalar günlük olarak takip edilerek, hesaplanan günlük kalori miktarını alıp almadıkları da değerlendirildi. Herhangi bir sebeple hesaplanan günlük kalori miktarını alamayan hastalar çalışma dışı bırakıldı. Hastaların serum glukoz düzeyleri 120-180 mg/dL aralığında olacak şekilde insülin infüzyonu uygulandı. Parenteral nütrisyon tedavisi süresince 1, 7 ve 14. günlerde kan örnekleri alındı. Serum albumin, total protein, Alanin Aminotransferaz (ALT), Aspartat Aminotransferaz (AST), Laktat Dehidrogenaz (LDH), Gama-Gulutamil Transferaz (GGT), Alkalen Fosfotaz (ALP), glukoz, trigliserit, kolesterol, Düşük Dansiteli Lipoprotein (LDL), Yüksek Dansiteli Lipoprotein (HDL), Aktive Parsiyel Tromboplastin Zamanı (APTT), Protrombin Zamanı (PT), Uluslararası Normalizasyon Oranı (INR), C-Reaktif Protein (CRP), prealbumin düzeyleri çalışıldı.

Istatistiksel analiz Medcalc (Medcalc Software, Mariakerke, Belgium, version 11.0.1.0) istatistik programı kullanılarak yapıldı. Tüm verilere Kolmogorov - Simirnov testi uygulandıktan sonra, gruplar arası değerlendirmede normal dağılım gösteren veriler için tek yönlü varyans analizi testi, çarpık dağılım gösteren veriler için Kruskall - Wallis testi kullanıldı. Grup içi değerlendirmede normal dağılım gösteren veriler için tekrarlayan ölçümlerin tek yönlü varyans analizi testi, çarpık dağılım gösteren veriler için Friedman testi kullanıldı. Nominal değerlerin gruplar arası karşılaştırımasında Ki-kare testi kullanıldı. $p<0,05$ anlamlı kabul edildi.

\section{Bulgular}

Çalışmaya dahil edilen 45 hastanın demografik verileri Tablo 1'de gösterilmektedir. Çalışmaya dahil edilen hastaların büyük çoğunluğu cerrahi nedenlere bağlı olarak enteral beslenmenin mümkün olmadığı hastalardır. Hastaların büyük çoğunluğuna yoğun bakım yatışlarının ilk 24 saatinde parenteral nütrisyon başlanmıştır.

Gruplar arasında ve grup içi karşılaştırmalarda 1. gün, 7. gün ve 14. gün serum glukoz ortalamaları arasında istatistiksel olarak anlamlı fark gözlenmedi.

Karaciğer fonksiyon testleri olarak değerlendirilen ALT, AST, GGT, ALP, total protein ve albümin düzeylerinde 3 
Türk Yoğun Bakım Derneği Dergisi / Journal of the Turkish Society of Intensive Care 2012;10: 52-8

ölçüm zamanında gruplar arası istatistiksel olarak anlamlı değişim gözlenmedi. Grup içi karşılaştırmalarda ise Grup 2 ve Grup 3'te 7. gün ve 14. gün GGT düzeyleri 1. güne göre ve Grup 3'te 14. gün ALP düzeyi 1. gün ve 7. güne göre istatistiksel olarak anlamlı derecede yüksek bulundu. Grup 2'de 7. gün ve 14. gün albümin değerleri 1. güne göre istatistiksel olarak anlamlı düşük bulundu (Tablo 2).

Lipid profili yönünden değerlendirildiğinde, gruplar arası 1. gün, 7. gün ve 14. gün trigliserid düzeyleri arasında fark gözlenmedi. Grup içi karşılaştırmalarda Grup 3'te 14. gün

Tablo 1. Olguların demografik verileri. (Değerler ortalama \pm SD veya ortanca (min-maks) olarak belirtilmiştir.)

\begin{tabular}{lcccc} 
& Grup 1 & Grup 2 & Grup 3 & p \\
\hline Yaş (yıl) & $66,93 \pm 18,53$ & $74,0 \pm 10,89$ & $61,13 \pm 21,41$ & 0,260 \\
Cinsiyet(E/K) & $7 / 8$ & $5 / 10$ & $3 / 12$ & 0,121 \\
Kilo $(\mathrm{kg})$ & $73,0 \pm 9,41$ & $72,86 \pm 6,57$ & $67,66 \pm 12,08$ & 0,235 \\
Boy $(\mathrm{cm})$ & $166,2 \pm 10,2$ & $163,86 \pm 7,26$ & $162,80 \pm 9,82$ & 0,589 \\
VKi $\left(\mathrm{kg} / \mathrm{m}^{2}\right)$ & $25,7(22,2-31,1)$ & $27,0(24,0-31,2)$ & $24,9(17,7-35,6)$ & 0,284 \\
\hline
\end{tabular}

VKi: Vücut kitle indeksi

Tablo 2. Grupların karaciğer enzimleri ve total protein değerlerinin karşılaştırılması

\begin{tabular}{|c|c|c|c|c|c|}
\hline & & 1. Gün & 7. Gün & 14. Gün & p \\
\hline Total protein & Grup 1 & $5,76 \pm 0,90$ & $5,68 \pm 1,04$ & $5,84 \pm 1,04$ & 0,796 \\
\hline \multirow[t]{3}{*}{$(g / d l)$} & Grup 2 & $6,15 \pm 1,08$ & $5,88 \pm 0,77$ & $5,78 \pm 0,71$ & 0,286 \\
\hline & Grup 3 & $5,87 \pm 1,06$ & $6,07 \pm 0,84$ & $5,92 \pm 0,92$ & 0,684 \\
\hline & $p$ & 0,564 & 0,498 & 0,913 & \\
\hline ALT & Grup 1 & $40,40 \pm 28,34$ & $37,80 \pm 33,59$ & $26,46 \pm 15,35$ & 0,342 \\
\hline \multirow[t]{3}{*}{$(\mathrm{U} / \mathrm{I})$} & Grup 2 & $51,80 \pm 68,98$ & $47,33 \pm 24,12$ & $37,13 \pm 24,13$ & 0,450 \\
\hline & Grup 3 & $31,06 \pm 28,09$ & $50,33 \pm 47,65$ & $71,00 \pm 85,79$ & 0,264 \\
\hline & $p$ & 0,391 & 0,357 & 0,339 & \\
\hline AST & Grup 1 & $57,13 \pm 44,49$ & $50,66 \pm 68,51$ & $37,93 \pm 25,71$ & 0,278 \\
\hline \multirow[t]{3}{*}{ (U/I) } & Grup 2 & $46,93 \pm 34,93$ & $57,26 \pm 27,24$ & $45,26 \pm 34,18$ & 0,167 \\
\hline & Grup 3 & $35,46 \pm 31,65$ & $53,13 \pm 37,95$ & $102,33 \pm 152,26$ & 0,081 \\
\hline & $p$ & 0,104 & 0,092 & 0,534 & \\
\hline GGT & Grup 1 & $80,66 \pm 98,97$ & $72,00 \pm 79,59$ & $103,40 \pm 135,94$ & 0,128 \\
\hline \multirow[t]{3}{*}{ (U/I) } & Grup 2 & $134,53 \pm 208,18$ & $147,66 \pm 121,35^{*}$ & $153,26 \pm 124,48^{*}$ & $0,032^{*}$ \\
\hline & Grup 3 & $137,26 \pm 204,84$ & $158,33 \pm 152,83^{\dagger}$ & $155,60 \pm 95,94^{\dagger}$ & $0,010^{\dagger}$ \\
\hline & $p$ & 0,468 & 0,072 & 0,070 & \\
\hline ALP & Grup 1 & $152,93 \pm 205,88$ & $159,20 \pm 241,18$ & $125,66 \pm 84,50$ & 0,241 \\
\hline \multirow[t]{3}{*}{ (U/I) } & Grup 2 & $135,33 \pm 116,78$ & $136,33 \pm 104,02$ & $137,93 \pm 102,76$ & 0,070 \\
\hline & Grup 3 & $93,93 \pm 90,65$ & $100,40 \pm 57,12$ & $135,33 \pm 82,67^{\ddagger}$ & $0,040^{\ddagger}$ \\
\hline & p & 0,297 & 0,781 & 0,790 & \\
\hline ALBUMIN & Grup 1 & $3,04 \pm 0,56$ & $2,87 \pm 0,60$ & $2,70 \pm 0,62$ & 0,550 \\
\hline \multirow[t]{3}{*}{ (g/dl) } & Grup 2 & $3,09 \pm 0,55 \beta$ & $2,71 \pm 0,31$ & $2,52 \pm 0,33$ & $0,01 \beta$ \\
\hline & Grup 3 & $3,0 \pm 0,74$ & $2,87 \pm 0,56$ & $2,74 \pm 0,68$ & 0,339 \\
\hline & $p$ & 0,617 & 0,769 & 0,958 & \\
\hline \multicolumn{6}{|c|}{ 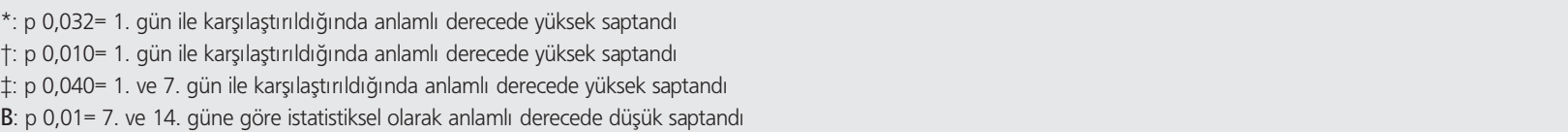 } \\
\hline
\end{tabular}


trigliserid düzeyleri 1. güne göre istatistiksel olarak anlamlı yüksek saptandı. Gruplar arası ve grup içi değerlendirmelerinde 1. gün, 7. gün, 14. gün kolesterol, $L D L$ ve $H D L$ değerleri arasında istatistiksel farklıık gözlenmedi (Tablo 3).

Gruplar arası ve grup içi karşılaştırmalarda 1. gün, 7. gün, 14. gün PT, INR ve aPTT değerlerinde istatistiksel olarak anlamlı değişim gözlenmedi.

Nutrisyon tedavisinin etkinliğini değerlendirmede kullanılan prealbümin, CRP (C-reaktif protein) ve transferrin

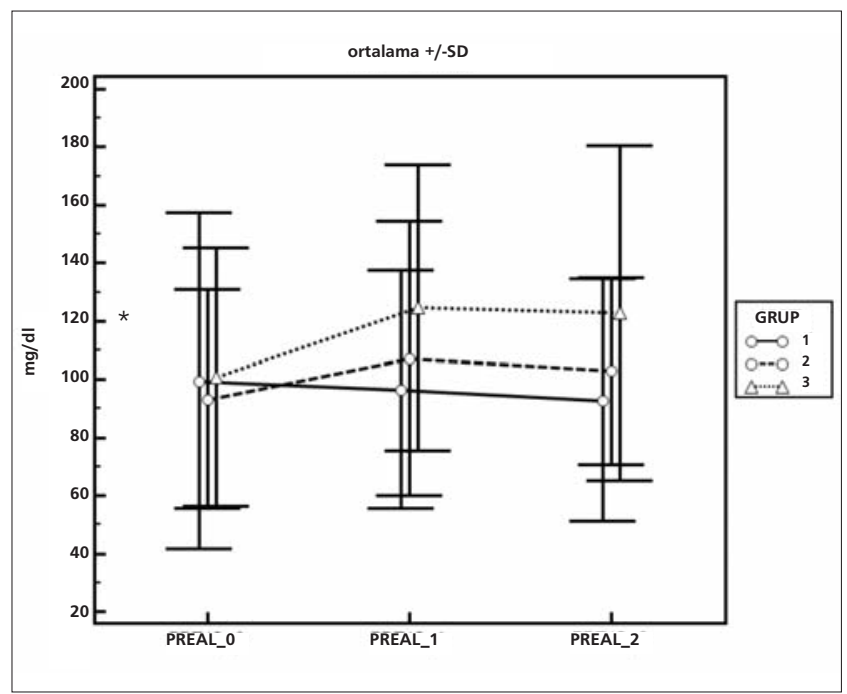

Şekil 1. Grupların prealbümin düzeyleri düzeyleri arasında gruplar arası ve grup içi karşılaştırmalarda istatistiksel olarak anlamlı farklılık bulunmadı. Ancak Grup 2 ve 3'te prealbümin değerlerinde istatistiksel olarak anlamlı olmayan klinik yükselme göze çarptı. CRP ve prealbümin beraber değerlendirildiğinde, Grup 2 ve 3'te prealbümin (Şekil 1) düzeyinde artış saptanırken; eş zamanlı olarak serum CRP (Şekil 2) düzeylerinde azalma saptandı. Bu değişiklikler istatistiksel olarak anlamlı değildi.

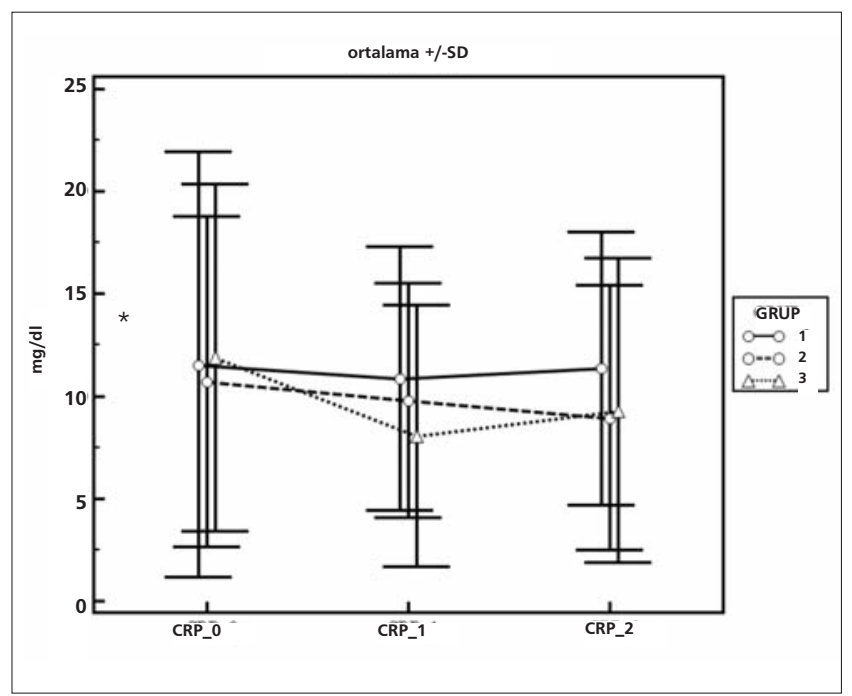

Şekil 2. Grupların CRP düzeyleri

\begin{tabular}{|c|c|c|c|c|c|}
\hline & & 1. Gün & 7. Gün & 14. Gün & $p$ \\
\hline \multirow{4}{*}{ Trigliserid (mg/dl) } & Grup 1 & $187,93 \pm 118,27$ & $171,46 \pm 106,49$ & $191,13 \pm 121,98$ & 0,356 \\
\hline & Grup 2 & $143,60 \pm 65,55$ & $171,0 \pm 79,81$ & $151,13 \pm 62,83$ & 0,356 \\
\hline & Grup 3 & $138,53 \pm 77,96$ & $167,86 \pm 84,54$ & $221,40 \pm 119,09 *$ & $0,025^{*}$ \\
\hline & $p$ & 0,266 & 0,890 & 0,205 & \\
\hline \multirow[t]{4}{*}{ Kolesterol (mg/dl) } & Grup 1 & $149,33 \pm 62,43$ & $137,66 \pm 50,66$ & $139,20 \pm 39,66$ & 0,520 \\
\hline & Grup 2 & $169,20 \pm 56,48$ & $168,13 \pm 54,42$ & $154,13 \pm 45,28$ & 0,246 \\
\hline & Grup 3 & $126,80 \pm 57,43$ & $139,26 \pm 43,49$ & $144,13 \pm 45,47$ & 0,326 \\
\hline & $p$ & 0,155 & 0,181 & 0,636 & \\
\hline \multirow[t]{4}{*}{ LDL (mg/dl) } & Grup 1 & $86,20 \pm 51,88$ & $75,00 \pm 41,24$ & $77,93 \pm 32,27$ & 0,501 \\
\hline & Grup 2 & $104,73 \pm 47,26$ & $101,53 \pm 46,29$ & $99,06 \pm 38,55$ & 0,778 \\
\hline & Grup 3 & $71,93 \pm 48,32$ & $80,80 \pm 33,65$ & $86,8 \pm 33,40$ & 0,392 \\
\hline & $p$ & 0,199 & 0,185 & 0,346 & \\
\hline \multirow[t]{4}{*}{ HDL (mg/dl) } & Grup 1 & $28,73 \pm 13,81$ & $26,73 \pm 10,91$ & $23,06 \pm 10,01$ & 0,235 \\
\hline & Grup 2 & $35,66 \pm 12,02$ & $28,80 \pm 9,96$ & $32,33 \pm 19,06$ & 0,278 \\
\hline & Grup 3 & $27,20 \pm 10,83$ & $26,0 \pm 8,24$ & $22,93 \pm 6,86$ & 0,189 \\
\hline & $p$ & 0,145 & 0,688 & 0,173 & \\
\hline
\end{tabular}

*: p 0,025=1. günle karşılaştııılığında istatistiksel olarak anlamlı derecede yüksek saptandı 


\section{Tartışma}

Bu çalışmanın sonucunda, üç farklı lipid içeren parenteral nutrisyon ürünü uygulanan hasta grupları arasında kan glukoz düzeyleri, karaciğer fonksiyon testleri, kanama profili, lipid profili, transferrin, CRP ve prealbümin düzeyleri yönünden anlamlı bir fark bulunmamıştır.

Klinik nütrisyon kılavuzlarında hastanın yoğun bakıma kabulünden sonraki ilk 24-48 saat içinde erken nütrisyon desteğine başlanması önerilmektedir (18-20). Parenteral nütrisyon ile enteral nutrisyon karşılaştırıldığında; parenteral nütrisyonda hedef kaloriye ulaşma zamanının daha kısa, hedef kaloriye ulaşma oranının ise daha yüksek olduğu görülmüştür (21-23). Çalışmamızda enteral yolun kullanılamadığı hastaların parenteral nütrisyon tedavileri takibe alınmıştır ve tüm hastalarda belirlenen hedef kaloriye ulaşılmıştır.

Klinik pratikte antropometrik ve laboratuar ölçümleri beslenme durumunun değerlendirilmesinde yardımcı olabilmekte ise de bu ölçümlerin genel olarak beslenmedeki değişikliklere karşı duyarsız oldukları bilinmektedir. Nitrojen dengesi, vücut proteinlerinin kaybı veya kazanılmasının bir göstergesi olabilir, ancak tek başına bir hedef değildir. Bu nedenle malnutrisyonda değişiklik gösteren dört plazma protein düzeyiyle ilgili olarak albüminin düşük, transferrinin orta derecede, prealbümin ve retinol bağlayıcı proteininse yüksek derecede duyarlı olduğu gösterilmiştir (24).Yoğun bakım ünitelerinde nutrisyon takibi yapılan malnutrisyonlu geriyatrik hastaların \%42,9'u kombine enteral-parenteral, $\% 3,1^{\prime} i$ enteral, \%18,5'i parenteral ve \%7,6'sı oral yollarla beslenmiştir. Hastaların serum protein değerleri, hastanede kalış süresi ve mortalite açısından fark görülmemiş, ayrıca hastaneye yatış ve nutrisyonel destek sonrası biyokimyasal parametreler arasında herhangi bir farklılık saptanmadığı bildirilmiştir. Nutrisyonel destek süresinin kısa olmasından (ortalama 10,95 99,55 gün) dolayı herhangi bir değişim kaydedilemediği sonucuna varılmıştır $(25,26)$. Çalışmamızda tüm olgular 14 gün boyunca takip edilmiş ve her üç grupta da biyokimyasal parametreler açısından farklıık tespit edilmemiştir.

Abad-Lacruz ve ark. (27)'nın başlangıç karaciğer fonksiyon testleri normal olan 29 inflamatuar barsak hastalığı olan hastayı dahil ettikleri ve enteral ve parenteral nutrisyonun karaciğer fonksiyon testleri üzerine etkilerini karşılaştırdıkları çalışmada, serum AST, ALT, ALP, GGT ve bilirubin ölçümleri haftalık olarak yapıldığında Total Parenteral Nütrisyon (TPN) uygulamalarının karaciğer fonksiyon testlerinde bozulmaya yol açtığı görülmüştür. Benzer şekilde, iki haftadan uzun süre, kalori alımları, enerji tüketimlerine göre ve non-protein kalorinin \% 50'si yağ olacak şekilde standardize edilmiş TPN uygulanan hastalarda karaciğer fonksiyon testlerinde \% 11-14 oranında artış tespit edilmiştir (28).

Parenteral nutrisyon sırasında hiperglisemi, elektrolit bozuklukları, böbrek ve karaciğer fonksiyon bozuklukları ve hipertrigliseridemi en sık karşılaşılan metabolik komplikasyonlardır (16). Uzun süreli parenteral nutrisyon alan erişkinlerde yapılan bir çalışmada; karaciğer enzim düzeylerinde \%25-100 oranında artış saptanırken; \%15-40 oranlarında da son dönem karaciğer hastalığı geliştiği saptanmıştır. Benzer şekilde, evde uzun süreli ( $>6$ ay) parenteral nutrisyon alan 162 hastanın değerlendirmesinde, 154 hastada anormal karaciğer enzim düzeyleri, çoğunda orta düzeyde ALP veya AST'de yükselme, 7 hastada ciddi karaciğer disfonksiyonu görülmüştür. Buna karşın sadece 1 hastada tamamen normal sınırlarda karaciğer enzim düzeyleri saptanmıştır (29). Çalışmamızda kısa süreli TPN uygulaması ile grup içi ve gruplar arasında serum AST ve ALT değerleri açısından istatistiksel olarak anlamlı bir fark saptanmamıştır. Buna karşın Grup 2 ve Grup 3'te 7. ve 14. günde GGT düzeyleri; Grup 3'te 14.günde ALP düzeyleri istatistiksel olarak anlamlı derecede yükselmiştir. ALT ve ALP yüksekliği parenteral nutrisyon sırasında en sık görülen karaciğer fonksiyon değişikliğidir (30).

TPN'nin genel komplikasyonları arasında, hematolojik değerler önemli bir role sahiptir ve lipid emülsiyonları ile ilişkilidir. Ayrıca, vitamin $\mathrm{K}$ parenteral nutrisyon solüsyonlarına eklenen multivitamin preparatlarında bulunmadığından, TPN desteği alan hospitalize hastalarda, $\mathrm{K}$ vitamini eksikliği gelişme riski vardır. Uzun süreli (4 haftaya kadar) TPN izlemi yapılan hastaların \%3,6'sında bazal değere göre INR'de yükselme saptanmıştır. Tüm yükselmeler çok az ve hiçbir hastada klinik olarak kanama görülmemiştir (31). Schepers ve ark. (32), parenteral nutrisyon uygulanan hastalarda intravenöz ve intramusküler $\mathrm{K}$ vitamini etkinliğini karşılaştırmıştır. PT ve aPTT zamanları arasında farklılık saptanmamış ve TPN alanlara düzenli olarak K vitamini eklemenin PT'de uzamayı önlediği sonucuna varılmıştır. Buna karşın, MCT/LCT ve LCT bazlı solüsyonların kısa süreli (ortalama 8 gün) kullanıldığı çalışmalarda PT, \%PT, trombin, fibrinojen, hemogram, proteinogram değerleri arasında farklılık saptanmamıştır. Ek olarak, her iki lipid solüsyonu benzer etkiye sahip olduğu, klinik olarak iyi tolere edildiği ve hemokoagülasyonda değişikliğe neden olmadığı vurgulanmıştır (33,34). Çalışmamızda her 3 grubun gruplar arası ve grup içi karşılaştırılmasında PT, aPTT ve INR düzeylerinde istatistiksel olarak anlamlı bir farklılık saptanmadı. Hiçbir hastada klinik olarak kanama görülmedi. 
Casati ve ark. (35), yoğun bakım ünitesinde TPN uygulanan 30 hastada yaptıkları çalışmada nutrisyonel destek verilmeden önce, TPN uygulamasının 3. ve 8. gününde alınan kan örneklerinde CRP düzeylerinde anlamlı değişiklik gözlememiştir. Çalışmanın sonucunda ayrıca prealbümin ve retinol bağlayıcı protein seviyelerinin arttı̆̆ı ve CRP düzeyleri ile bir ilişkileri olmadığı kanısına varılmıştır. Çalışmamızda her 3 gruptaki olgularda serum CRP düzeyleri açısından gruplar arasında ve grup içinde anlamlı farklılık saptanmadı. Nijveldt ve ark. (36), 20 cerrahi yoğun bakım hastası üzerinde gerçekleştirilen çalışmalarında, bir grup hastaya \%100 LCT bazlı bir lipid solüsyonu, diğer gruptaki hastalara \%50 MCT/LCT ve \%50 LCT karışımı lipid içeren parenteral nutrisyon verilmiş. Her iki gruptaki hastalarda kan kolesterol, trigliserid, prealbümin, transferrin değerleri değerlendirildiğinde anlamlı bir fark bulunmamıştır.

TPN uygulanan 28 hastada 4 farklı tip lipid içeren nutrisyon ürünü kullanımış. TPN'nin 1. ve 6. günlerinde trigliserid, kolesterol, lipoproteinler ve serum yağ asitleri düzeyleri yönünden gruplar karşılaştıııımıştır. Gruplar arasında değerlendirilen parametrelerin düzeyleri benzer bulunmuştur (37). Çalışmamızda her 3 grup arasında lipid profilleri karşılaştııldığında istatistiksel olarak anlamlı farklılık gözlenmedi. Ancak grup içi karşılaştırmalarda Grup $3^{\prime}$ te, 14. gün trigliserid düzeyleri 1. güne göre istatistiksel olarak anlamlı derecede yüksek saptanmıştır.

Enteral nutrisyonun parenteral nutrisyona göre üstün olduğu kanaatinin yaygınlığına rağmen, çok sayıda araştırma ve bulguya dayalı veriler, bunun yanlış olabileceğini öne sürmektedir. Enteral nutrisyon, enerji alımı hedeflerine ulaşamadan başarısızlığa uğrayabilir ve komplikasyon riski önemli derecede yüksek olabilir. Gastrointestinal traktusun fonksiyonel olduğu durumlarda enteral nutrisyona mümkün olan en kısa sürede başlanılması önerilmektedir (1). Ancak, enteral nutrisyonun yoğun bakım hastalarında her zaman tek başına tüm nutrisyonel ihtiyacı karşılayamadığı, yetersiz enerji ve protein alımına neden olduğu bilinmektedir. Erken başlanan yüksek doz enteral nutrisyon ise yüksek komplikasyon riskiyle bağlantııdır. Kesin sonuç henüz bulunmamıştır ve bu konudaki araştırmalar devam etmektedir. Yoğun bakımda yapılan çalışmaların metaanalizleri, parenteral nutrisyonla enteral nutrisyon arasında hastanede ve yoğun bakımda kalış süreleri ve mortalite yönünden bir fark olmadığını, hatta beslenme hedeflerine daha etkin ulaşıldığını göstermiştir.

Sonuç olarak; 14 gün boyunca soya yağı, zeytinyağı ve MCT/LCT bazlı parenteral nutrisyon ürünü ile beslenen yoğun bakım hastalarında çalş̧lan biyokimyasal parametreler ve nutrisyon etkinliği açısından fark bulunmamıştır. Ancak çalışmamızda gruplardaki istatistiksel olarak anlamlı olmayan değişikliklere bakarak daha büyük vaka gruplarıyla çalışma planlanmasının yararlı olacağı sonucuna varılımıştır.

\section{Kaynaklar}

1. Sobotka L, Soeters $P B$, Raguso CA, Jolliet P, Pichard C. Nutritional support in critically ill and septic patients. In: Lubos Sobotka, edt: Basics in clinical nutrition.3rd Prag: House Galen; 2004. p.294-9

2. Moore FA, Feliciano DV, Andrassy RJ, McArdle AH, Booth FV, Morgenstein-Wagner TB, et al. Early enteral feeding, compared with parenteral, reduces postoperative septic complications. The results of a meta-analysis. Ann Surg 1992;216:172-83.

3. Stratton RJ, Elia M. Who benefits from nutritional support: what is the evidence? Eur J Gastroenterol Hepatol 2007;19:353-8.

4. Demirkıran O. ESPEN Parenteral Nütrisyon Rehberleri: Yoğun Bakım. Oya Kutlay, Haldun Gündoğdu, editörler. ESPEN Parenteral Nütrisyon Rehberi. 1. Baskı. 2011. p. 38-52.

5. Van den Berghe G. The neuroendocrine response to stres is a dynamic process. Best Pract Res Clin Endocrinol Metab 2001;15:405-19.

6. Landry DW, Oliver JA. The pathogenesis of vasodilatory shock. N Engl J Med 2001;345:588-95.

7. Rand WM, Pellett PL, Young VR. Meta-analysis of nitrogen balance studies for estimating protein requirements in healty adults. Am J Clin Nutr 2003;77:109-27.

8. Millward DJ. The hormonal control of protein turnover. Clin Nutr 1990:9:115-26.

9. Klein S, Kinney J, Jeejeebhoy K, Alpers D, Hellerstein M, Murray $M$, et al. Nutrition support in clinical practice: review of published data and recommendations for future research directions. National Institutes of Health, American Society for Parenteral and Enteral Nutrition, and American Society for Clinical Nutrition. JPEN J Parenter Enteral Nutr 1997;21:133-56.

10. Mathru M, Dries DJ, Zecca A, Fareed J, Rooney MW, Rao TL. Effect of fast vs. slow intralipid infusion on gas exchange, pulmonary hemodynamics, and prostaglandin metabolism. Chest 1991;99:426-9.

11. Smyrniotis VE, Kostopanagiotou GG, Arkadopoulos NF, Theodoraki KA, Kotsis TE, Lambrou AT, et al. Long-chain versus medium-chain lipids in acute pancreatitis complicated by acute respiratory distress syndrome: effects on pulmonary hemodynamics and gas exchange. Clin Nutr 2001;20:139-43.

12. Suchner U, Katz DP, Fürst $P$, Beck K, Felbinger TW, Senftleben U, et al. Effects of intravenous fat emulsions on lung function in patients with acute respiratory distress syndrome or sepsis. Crit Care Med 2001;29:1569-74.

13. Masclans JR, Iglesia R, Bermejo B, Picó $M$, Rodriguez-Roisin R, Planas M. Gas exchange and pulmonary haemodynamic responses to fat emulsions in acute respiratory distress syndrome. Intensive Care Med 1998;24:918-23.

14. Suchner U, Katz DP, Fürst $P$, Beck K, Felbinger TW, Thiel M, et al. Impact of sepsis, lung injury, and the role of lipid infusion on circulating prostacyclin and thromboxane $A(2)$. Intensive Care Med 2002;28:122-9

15. Lekka ME, Liokatis S, Nathanail C, Galani V, Nakos G. The impact of intravenous fat emulsion administration in acute lung injury. Am J Respir Crit Care Med 2004;169:638-44.

16. Bacakoğlu F. Yoğun bakım hastalarında beslenme.[Nutrition in critically ill patients.] Solunum 2008;10:54-61.

17. Schofield WN. Predicting basal metabolic rate, new standards and review of previous work. Hum Nutr Clin Nutr 1985;39 (Suppl 1):5-41. 
18. Hammarqvist F. Can it all be done by enteral nutrition? Curr Opin Clin Nutr Metab Care 2004; 7:183-7.

19. Heidegger CP, Romand JA, Treggiari MM, Pichard C. Is it now time to promote mixed enteral and parenteral nutrition for the critically ill patient? Intensive Care Med 2007;33: 963-9.

20. Scurlock C, Mechanick JI. Early nutrition support in the intensive care unit: a US perspective. Curr Opin Clin Nutr Metab Care 2008;11: 152-5.

21. Braga M, Gianotti L, Gentilini O, Parisi V, Salis C, Di Carlo V. Early postoperative enteral nutrition improves gut oxygenation and reduces costs compared with total parenteral nutrition. Crit Care Med 2001;29:242-8

22. Woodcock NP, Zeigler D, Palmer MD, Buckley P, Mitchell CJ, MacFie J. Enteral versus parenteral nutrition: a pragmatic study. Nutrition 2001:17:1-12.

23. De Jonghe B, Appere-De-Vechi C, Fournier M, Tran B, Merrer J, Melchior JC, et al. A prospective survey of nutritional support practices in intensive care unit patients: what is prescribed? What is delivered? Crit Care Med 2001;29:8-12.

24. Delgado AF, Kimura HM, Cardoso AL, Uehara D, Carrazza FR. Nutritional follow-up of critically ill infants receiving short term parenteral nutrition. Rev Hosp Clin Fac Med Sao Paulo 2000;55:3-8.

25. Atalay BG, Yagmur C, Nursal TZ, Atalay H, Noyan T. Use of subjective global assessment and clinical outcomes in critically ill geriatric patients receiving nutrition support. JPEN Parenter Enteral Nutr 2008;32:454-9.

26. Bos $C$, Benamouzig $R$, Bruhat $A$, Roux $C$, Valensi $P$, Ferrière $F$, et al. Nutritional status after short-term dietary suplementation in hospitalized malnourished geriatric patients. Clin Nutr 2001;20:225-33.

27. Abad-Lacruz A, González-Huix F, Esteve M, Fernández-Bañares $F$, Cabré E, Boix J, et al. Liver function tests abnormalities in patients with inflammatory bowel disease receiving artificial nutrition: a prospective randomized study of total enteral nutrition vs total parenteral nutrition. JPEN J Parenter Enteral Nutr 1990;14:618-21.
28. Carpentier YA, Van Brandt M. Effect of total parenteral nutrition on liver function. Acta Chir Belg 1981;80:141-4

29. Salvino R, Ghanta R, Seidner DL, Mascha E, Xu Y, Steiger E, et al. Liver failure is uncommon in adults receiving long-term parenteral nutrition. JPEN J Parenter Enteral Nutr 2006;30:202-8.

30. Lindor KD, Fleming CR, Abrams A, Hirschkorn MA. Liver function values in adults receiving total parenteral nutrition. JAMA 1979; 241:2398-400

31. Duerksen DR, Papineau N. The prevalence of coagulation abnormalities in hospitalized patients receiving lipid-based parenteral nutrition. JPEN J Parenter Enteral Nutr 2004:28:30-3.

32. Schepers GP, Dimitry AR, Eckhauser FE, Kirking DM. Efficacy and safety of low-dose intravenous versus intramuscular vitamin $\mathrm{K}$ in parenteral nutrition patients. JPEN J Parenter Enteral Nutr 1988:12:174-7.

33. Demirer $S$, Aydintuğ $S$, Ustün $C$, Türkmen E, Tüzün $A$, Simsek $S$, et al. Comparison of the efficacy of medium chain triglycerides with long chain triglycerides in total parenteral nutrition in patients with hematologic malignancies undergoing peripheral blood stem cell transplantation. Clin Nutr 2000;19:253-8.

34. Martínez MJ, Folch N, Torregrosa N, Alfaro A, Obaldia MC. Coagulation and total parenteral nutrition: the effect of 2 lipid emulsions. Nutr Hosp 1995; 10:74-80.

35. Casati A, Muttini S, Leggieri C, Colombo S, Giorgi E, Torri G. Rapid turnover proteins in critically ill ICU patients. Negative acute phase proteins or nutritional indicators? Minerva Anestesiol 1998;64:345-50.

36. Nijveldt RJ, Tan AM, Prins HA, de Jong D, van Rij GL, Wesdorp RI, et al. Use of a mixture of medium-chain triglycerides and longchain triglycerides versus long-chain triglycerides in critically ill surgical patients: a randomized prospective double-blind study. Clin Nutr 1998:17:23-9.

37. Puiggròs $C$, Sánchez J, Chacón P, Sabín P, Roselló J, Bou R, et al. Evolution of lipid profile, liver function, and pattern of plasma fatty acids according to the type of lipid emulsion administered in parenteral nutrition in the early postoperative period after digestive surgery. JPEN J Parenter Enteral Nutr 2009;33:501-12. 